\title{
Resource Collection by Honeybees (Apis mellifera) on Yellow Melon (Cucumis melo) Flowers
}

\author{
Márcia F. Ribeiro ${ }^{1}$, Eva M. S. Silva ${ }^{2}$, Lúcia H. P. Kiill ${ }^{1}$, Katia M. M. Siqueira ${ }^{3}$, Márcia S. Coelho ${ }^{4}$ \\ \& Mara P. Silva ${ }^{4}$ \\ ${ }^{1}$ Embrapa Semiárido, Petrolina, PE, Brazil \\ ${ }^{2}$ Universidade do Vale do São Francisco (UNIVASF), Petrolina, PE, Brazil \\ ${ }^{3}$ Universidade do Estado da Bahia (UNEB), Petrolina, PE, Brazil \\ ${ }^{4}$ Petrolina, PE, Brazil \\ Correspondence: Márcia F. Ribeiro, Embrapa Semiárido, Petrolina, PE, Brazil. E-mail: \\ marcia.ribeiro@embrapa.br \\ Received: December 20, 2016 \\ Accepted: February 5, 2017 \\ Online Published: March 15, 2017 \\ doi:10.5539/jas.v9n4p15 \\ URL: https://doi.org/10.5539/jas.v9n4p15
}

\begin{abstract}
This study aimed to analyze the details of collection of floral resources (pollen and nectar) by honeybees (Apis mellifera) on male and hermaphrodite flowers of melon (Cucumis melo). The experiments were conducted in areas located at Embrapa Semiárido and Embrapa Produtos e Mercado, Petrolina, state of Pernambuco, in November and December 2011, with crop of a hybrid yellow 10/00 F1 melon. Honeybee colonies housed in Langstroth hives, uniform concerning the number of individuals and brood area were used. The four experimental areas ( 0.5 ha each), received respectively $0,1,2$ and 3 hives, from the first day on which the hermaphrodite flowers appeared to the end of the flowering period of the melon crop. The results showed that the bees visited more the hermaphrodite than the male flowers, in order to collect the resources (pollen and nectar), in all areas where honeybee hives were placed. In general, independently from the number of hives, the resource most collected was nectar. Pollen collection occurred mainly at the first hours of the morning, while nectar was collected throughout the day.
\end{abstract}

Keywords: honeybees, foraging behavior, melon flowers, pollen, nectar

\section{Introduction}

Bees feed almost exclusively on pollen and nectar (Silveira et al., 2002). Thus, they need to visit a large number of flowers to collect the protein (pollen) and energy (nectar) resources to feed on and, in the case of social bees, such as honeybees (Apis mellifera), they must collect a lot of food to maintain a large number of individuals in the colonies (on average, 80,000 individuals). Thus, they need to visit many flowers and consequently act as effective pollinators. In fact, honeybees are considered the most important pollinators of agricultural crops (Witter et al., 2014; Giannini et al., 2015a, 2015b; Sousa et al., 2016). An example is melon (Cucumis melo), which depends entirely on pollinating agents for fruit production (Giannini et al., 2015b). Honeybees visit the male and hermaphrodite flowers throughout the day to collect resources, and do have a preference for the hermaphrodite, although most flowers are male (Siqueira et al., 2011; Ribeiro et al., 2015). However, there are few detailed studies on the behavior of these bees on flowers.

According to Siqueira et al. (2011), the productivity of melon is conditioned to the number of hives of honeybees used in the areas to perform pollination. In a recent study, Ribeiro et al. (2015) found that for commercial fruit production in the regions of Petrolina (state of Pernambuco) and Juazeiro (state of Bahia), the number of bee hives should be 4/ha (and/or four hives per 3,000 melon plants, once the spacing between plants may vary in the areas). Increasing the number of hives increased drastically the number of bees present at flowers. Thus, areas which received 3 hives had, in fact, an excess of honeybees on melon flowers, provoking aggressiveness and competition between them for the flower resources. Consequently this area was not the one that presented the best results in relation to the production of commercial fruits and, the expected effect (i.e., best pollination results) was not reached. So, it would be necessary to know details on the collection behavior of bees' in these situations. In this way, the present study aimed to analyze the details of collection of floral resources (pollen and 
nectar) along the entire day on flowers of melon (Cucumis melo), in areas with different densities of hives of honeybees (Apis mellifera).

\section{Method}

\subsection{Study Areas}

The experiments were conducted in areas located in Petrolina, state of Pernambuco. The region is semi-arid, with dry climate, and average annual rainfall of $600 \mathrm{~mm}$, concentrated in three months of the year. The four experimental areas ( 0.5 ha each) were located at Embrapa Semiárido: Campo Experimental de Bebedouro $\left(09^{\circ} 08^{\prime} 07^{\prime \prime} \mathrm{S} 40^{\circ} 18^{\prime} 17^{\prime \prime} \mathrm{W}\right)$ and Embrapa Serviços, Produtos e Mercado (SPM) (09 $\left.03^{\prime} 08^{\prime \prime} \mathrm{S} 40^{\circ} 17^{\prime} 49^{\prime \prime} \mathrm{W}\right)$. All areas were subjected to the same soil preparation and fertilization, drip irrigation system, use of mulching and native vegetation in the surroundings. The same areas and crops described in the work of Ribeiro et al. (2015) were used.

\subsection{Material}

Melon crops were planted in October 2011, with an interval of 26 days. Yellow hybrid melon seeds 10/00 F1 were used, with spacing of $0.4 \mathrm{~m}$ and $2 \mathrm{~m}$ between plants and rows, respectively, totaling 6,250 plants $/ 0.5$ ha and 25,000 plants in the four areas (2 ha).

Apis mellifera Langstroth hives, with uniform characteristics in relation to the amount of brood ( $60 \%$ brood area) and estimated number of foragers (around 40,000 individuals), were introduced into the crop areas. Three areas received 1, 2 and 3 hives, respectively, and the last area received no hive, as a control. The hives were placed on the edges of the areas in the shade and at a safe distance (about $300 \mathrm{~m}$ ) so that there would be no interference with routine crop practices. They were introduced on the first day on which the hermaphrodite flowers appeared, that is, near the $15^{\text {th }}$ day after the seeds were sown, and were maintained until the end of the flowering period (about 25 days).

\subsection{Sampling Procedures}

\subsubsection{Sample Size}

Observations were made on five consecutive days, in November and December 2011, from 5 a.m. to 6 p.m., without intervals. The flowers used were located in the midlines of the crop areas and the sample size was 18 ( 1 hive) or 20 (0, 2, and 3 hives), for each floral type: male flowers (MF) and hermaphrodites flowers (HF). Thus, the total number of flowers was 78 , for each floral type.

\subsubsection{Measures}

Details of bees' behavior were observed to record whether they were collecting nectar $(\mathrm{N})$ or pollen $(\mathrm{P})$ during each floral visit. Thus, bees introducing their glossa on the basis of the flower were searching for $\mathrm{N}$ at the nectary, and were registered as $\mathrm{N}$ collectors. On the other hand, bees manipulating the anthers and depositing pollen grains at the corbiculae where obviously collecting $\mathrm{P}$ and were registered as P collectors.

\subsubsection{Statistical Analysis}

Averages were calculated for elaborate the Figure 1 and Table 1. Comparisons were made throughout the non-parametric tests: Kruskal-Wallis and Mann-Whitney (Zar, 2010).

\section{Results}

The results for the collection of resources by honeybees throughout the day in the areas with different densities of hives are shown in Figure 1. 


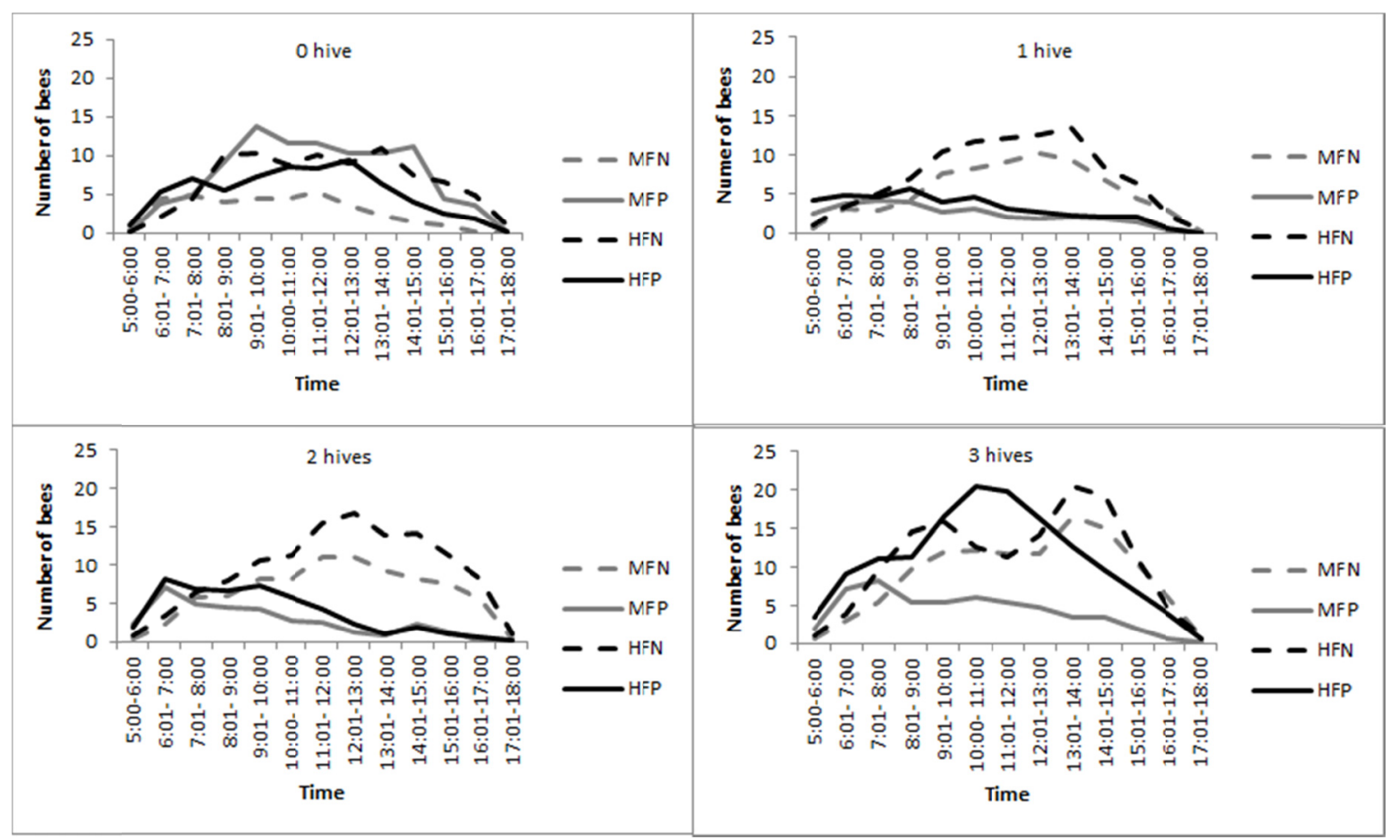

Figure 1. Resource collection: nectar $(\mathrm{N})$ and pollen $(\mathrm{P})$ by honeybees (Apis mellifera), on hermaphrodite (HF) and male (MF) flowers of melon (Cucumis melo), along the day, in areas with different densities of hives: 0, 1, 2 and 3 hives

Note. $\mathrm{MFN}=$ on male flower, collecting nectar; $\mathrm{MFP}=$ on male flower, collecting pollen; $\mathrm{HFN}=$ on hermaphrodite flower, collecting nectar; HFP = on hermaphrodite flower, collecting pollen).

In general, regardless of the number of hives, in the early hours of the morning, $\mathrm{P}$ (continuous lines) was the most collected resource. However, from 8 a.m. to 9 a.m. the situation was reversed and N (dotted lines) became the most intensely collected resource by the honeybees, a behavior that prevailed throughout the day.

On Figure 1 one can see that, in relation to $\mathrm{N}$ (dotted lines), in all situations there was a greater collection of this resource on HF than on MF. In addition, there was a gradual trend of increased intensity of resource collection with increasing number of hives. Although there was a collection of $\mathrm{N}$ throughout the day, both on $\mathrm{HF}$ and MF, there was an increase between 8 a.m. and 2 p.m., in situations of 0 and 1 hive; 10 a.m. and 4 p.m., for 2 hives; and two peaks, around 9 a.m. and 2 p.m., with 3 hives.

As for P (continuous lines), again, the same general pattern was observed: greater collection of this resource on HF than on MF, except in the situation without hives. Moreover, the difference was even greater in the situation with 3 hives. There was also collection of $\mathrm{P}$ throughout the day, with a very evident peak around $10 \mathrm{a} . \mathrm{m}$. in the area with 3 hives, mainly for HF.

Comparing the collection of resources by honeybees for the two floral types at areas with the different number of hives, the differences were significant for both resources ( $\mathrm{N}=78$ flowers, Kruskal-Wallis). For HF, P collection presented $\mathrm{P}=0.00$ and $\mathrm{N}, \mathrm{P}=0.02$. For $\mathrm{MF}$, both and $\mathrm{N}$ had $\mathrm{P}=0.00 . \mathrm{N}$ was, in fact, the most collected resource.

Table 1 presents the means $(\mathrm{M})$ and standard deviations (SD) for the number of bees collecting resources (P and $\mathrm{N}$ ) on the two floral types (HF and MF), throughout the day, and throughout the experimental period (13 time intervals/day on five consecutive days). These data reinforced the greater collection of resources (both $\mathrm{P}$ and $\mathrm{N}$ ) on HF, except for the situation of 0 beehive, where the highest value was obtained for MF. Analyzing only the $\mathrm{MF}$, in most cases, $\mathrm{N}$ was the most collected resource, in all densities of hives, except for 0 beehive. As for HF, $\mathrm{N}$ was also the most collected resource, except for the situation with 3 hives (although in this case the mean values were very similar for $\mathrm{P}$ and $\mathrm{N}$, Table 1). 
Table 1. Number of honeybees (Apis mellifera) collecting pollen $(\mathrm{P})$ or nectar $(\mathrm{N})$ on each floral type (male flower: MF and hermaphrodite flower: HF) of melon (Cucumis melo), throughout the observation period. ( 0,2 and 3 hives: $\mathrm{N}=20$ flowers; 1 hive: $\mathrm{N}=18$ flowers)

\begin{tabular}{|c|c|c|c|c|c|c|c|c|}
\hline \multirow{2}{*}{ Floral type } & \multicolumn{2}{|c|}{0 hive } & \multicolumn{2}{|c|}{1 hive } & \multicolumn{2}{|c|}{2 hives } & \multicolumn{2}{|c|}{3 hives } \\
\hline & $M(S D) P$ & $\mathrm{M}(\mathrm{SD}) \mathrm{N}$ & $\mathrm{M}(\mathrm{SD}) \mathrm{P}$ & $\mathrm{M}(\mathrm{SD}) \mathrm{N}$ & $M(S D) P$ & $\mathrm{M}(\mathrm{SD}) \mathrm{N}$ & $M(S D) P$ & $\mathrm{M}(\mathrm{SD}) \mathrm{N}$ \\
\hline MF & $65.2(45.3)^{\mathrm{a}, \mathrm{A}}$ & $110.9(64.1)^{\mathrm{a}, \mathrm{B}}$ & $42.2(23.3)^{\mathrm{a}, \mathrm{A}}$ & $97.1(61.5)^{\mathrm{a}, \mathrm{B}}$ & $53.2(42.2)^{\mathrm{a}, \mathrm{A}}$ & $131.1(71.5)^{\mathrm{a}, \mathrm{B}}$ & $83.3(49.7)^{\mathrm{a}, \mathrm{A}}$ & $177.5(104.0)^{\mathrm{a}, \mathrm{B}}$ \\
\hline $\mathrm{HF}$ & $104.1(61.2)^{\mathrm{b}, \mathrm{A}}$ & $132.7(75.8)^{\mathrm{a}, \mathrm{A}}$ & $57.4(31.5)^{\mathrm{a}, \mathrm{A}}$ & $130.9(83.0)^{\mathrm{a}, \mathrm{B}}$ & $74.5(58.6)^{\mathrm{a}, \mathrm{A}}$ & $187.5(105.4)^{\mathrm{b}, \mathrm{B}}$ & $217.9(125.0)^{\mathrm{b}, \mathrm{A}}$ & $214.7(128.5)^{\mathrm{a}, \mathrm{A}}$ \\
\hline
\end{tabular}

Note. Significance letters for P values, Mann-Whitney test: comparisons made in the columns are in lower cases; comparisons made in lines are in capitals.

Comparisons considering the columns of Table 1, i.e., in each situation of hives $(0,1,2$, and 3$)$, for both floral types $(\mathrm{MF}$ and $\mathrm{HF})$, considering one resource $(\mathrm{P}$ or $\mathrm{N})$ each time, showed significant differences $(\mathrm{P}<0.05$, Mann-Whitney test) only for: $\mathrm{P}$, in areas with 0 hive and 3 hives, and $\mathrm{N}$, with 2 hives. In all other comparisons, the differences were not significant.

On the other hand, when the lines of Table 1 were taken into account, i.e., in each situation of hives $(0,1,2$, and 3 ), for one floral type at time (MF or HF), between the resources ( $\mathrm{P}$ and $\mathrm{N})$, almost all differences were significant $(\mathrm{P}<0.05$, Mann-Whitney test), except for HF: 0 hive and 3 hives.

Finally, in order to evaluate the collected resources ( $\mathrm{P}$ and $\mathrm{N}$ ) in each floral type (MF and HF) comparisons were made in the extreme situations of hives ( 0 and 3). The results showed that both resources were indeed significantly different in most comparisons $(\mathrm{P}<0.05$, Mann-Whitney test), i.e., they were most collected by the bees in the area with 3 hives. The only exception was for the P in MF, where similar number of bees was found collecting this resource in both situations of hives.

\section{Discussion}

Concerning the period of time of resources collection, the pattern showed in Figure 1 was similar to that found by Kiill et al. (2011), in the same region, with different types of melon. Sousa et al. (2012) studied honeybee activities on yellow melon flowers in the state of Ceará and found similar results as well, that is, initial collection of $\mathrm{P}$ and then $\mathrm{N}$, although with greater differences and at other times (from 11 a.m.). However, the methodology used by these authors was distinct.

Tschoeke et al. (2015) investigated some types of melon in a cerrado region, and also observed that $\mathrm{P}$ was collected more than $\mathrm{N}$ up to 12 a.m. on MF, and until 10 a.m. on HF. At the end of the afternoon, in both floral types the $\mathrm{N}$ was collected more than the $\mathrm{P}$, but these authors also used a different method from that in the present work.

Regarding the amount of bees engaged in P and N collection, however, Sousa et al. (2012) found opposite results: a higher number of bees collected P, compared to N. However, as already mentioned, the methodology used by these authors was different and they considered not all the times analyzed in the present study, since the intervals of observation occurred every two hours and in this investigation, the observations were continuous.

Table 1 showed similar results to those registered by Hoz (2007) who studied melon in Panama.

Regarding the number of hives, indeed a larger resource collection was found in the area with a larger number of introduced beehives. However, as described previously (Ribeiro et al., 2015), in areas with 3 hives (or 6/ha) there is a greater competition by resources and the production of commercial fruits is not the best. Therefore, although there was found a larger number of bees collecting resources (as found in this work), probably they were getting a smaller amount of them and the pollination process could be affected.

The results presented here showed that $\mathrm{N}$ was the most collected resource, and for this reason it is possible that this resource was the most offered by the plants (more than P). Although it was not measured in this experiment, other studies confirmed that. Kiill et al. (2014), who examined two hybrids of melon in the same region, also presented similar results.

As already demonstrated (Ribeiro et al., 2015), honeybees in fact do prefer HF, regardless of the number of hives in the melon crop area, and this is probably due to the large concentration of nectar in those flowers (Siqueira et al., 2011). These authors found from 3 to almost 5 times larger $\mathrm{N}$ amounts in HF than in MF throughout the day, and they concluded this was the reason why the first ones were more attractive for the bees. The results found in this paper confirm that. 
The type of resource collected may also be related to the time of stay of the bees on the flower. Previous studies (Ribeiro et al., submitted), even using different methodology, showed that the HF received longer visits than MF, mainly in the morning. This would indicate that at this moment the bees would be collecting P, which should take more time to be obtained, since the grains need to be removed from the anthers by the bees, and then stored in their corbiculae. Tschoeke et al. (2015) also claimed that bees spent significantly more time collecting P than N.

\section{Conclusions}

The observations showed a greater collection of $\mathrm{N}$ than $\mathrm{P}$ on both floral types, in most cases, and mainly in the area with a larger number of hives, as expected. In addition, there was a preference of bees for HF, regardless of the density of hives in the crop areas. Therefore, this bee behavior benefits the pollination process, although there is a greater amount of MF.

\section{References}

Giannini, T. C., Boff, S., Cordeiro, G. D., Cartolano, J. R., Veiga, A. K., Imperatriz-Fonseca, V. L., \& Saraiva, A. M. (2015a). Crop pollinators in Brazil: A review of reported interactions. Apidologie, 46, 209-223. http://dx.doi.org/10.1007/s13592-014-0316-z

Giannini, T. C., Cordeiro, G. D., Freitas, B. M., Saraiva, A. M., \& Imperatriz-Fonseca, V. L. (2015b). The dependence of crops for pollinators and the economic value of pollination in Brazil. Journal of Economic Entomology, 10, 849-857. http://dx.doi.org/ 10.1093/jee/tov093

Hoz, J. C., \& Di Trani, de la H. (2007). Visita de abejas (Apis mellifera, Hymenoptera: Apoidea) a flores de melón Cucumis melo (Cucurbitaceae) en Panamá. Revista de Biologia Tropical., 55, 677-680.

Kiill, L. H. P., Coelho, M. S, Siqueira, K. M. M., \& Costa, N. D. (2011). Avaliação do padrão de visitação de Apis mellifera em três cultivares de meloeiro em Petrolina-PE, Brasil, Revista Brasileira de Fruticultura, 33, 455-460. http://dx.doi.org/10.1590/S0100-29452011000500060

Kiill, L. H. P., Feitoza, E. A., Siqueira, K. M. M., Ribeiro, M. F., \& Silva, E. M. S. (2016). Evaluation of floral characteristics of melon hybrids (Cucumis melo L.) in pollinator attractiveness. Revista Brasileira de Fruticultura, 38, 531. http://dx.doi.org/10.1590/0100-29452016531

Kiill, L. H. P., Siqueira, K. M. M., Coelho, M. S., Silva, T. A., Gama, D. R. S., Araújo, D. C. S., \& Pereira Neto, J. (2014). Frequency and foraging behavior of Apis mellifera in two melon hybrids in Juazeiro, state of Bahia, Brazil. Ac. Bras. de Ciências, 4, 2049-2055. http://dx.doi.org/ 10.1590/0001-3765201420130376

Ribeiro, M. F., Silva, E. M. S., Lima Júnior, I. O., \& Kiill, L. H. P. (2015). Honey bees (Apis mellifera) visiting flowers of yellow melon (Cucumis melo) using different number of hives. Ciência Rural, 45, 1768-1773. http://dx.doi.org/10.1590/0103-8478cr20140974

Silveira, F. A., Melo, G. A. R., \& Almeida, E. A. B. (2002). Abelhas Brasileiras. Sistemática e Identificação (1st ed.). Belo Horizonte: Ministério do Meio ambiente e Fundação Araucária. https://doi.org/10.1590/ S0100-39842002000500012

Siqueira, K. M. M., Kiill, L. H. P., Gama, D. R. S., Araújo, D. C. S., \& Coelho, S. C. (2011). Comparação do padrão de floração e de visitação do meloeiro do tipo amarelo em Juazeiro-BA. Revista Brasileira de Fruticultura, 33, 455-460. http://dx.doi.org/10.1590/S0100-29452011000500063

Siqueira, K. M. M., Kiill, L. H. P., Martins, C. F., \& Silva, L. T. (2012). Ecologia da polinização de Psidium guajava L., (Myrtaceae): Riqueza, frequência e horário de atividades de visitantes florais em um sistema agrícola. Magistra, 24, 150-157.

Sousa, R. M., Aguiar, O. S., Freitas, B. M., Maracajá, P. B., \& Andrade, C. B. M. (2012). Grazing behavior of Africanized honeybees (Apis mellifera L.) in flowers of yellow melon (Cucumis melo L.). Revista Verde, 7 , 233-238.

Sousa, R. M., Aguiar, O. S., Freitas, B. M., Silveira Neto, A. A., \& Pereira, T. F. C. (2009). Requerimentos de polinização do meloeiro (Cucumis melo) no município de Acaraú-CE-Brasil. Revista Caatinga, 22(1), 238-242.

Sousa, R. M., Cunha, M. B. Ribeiro, D. C. F., Silva, N. C. B., \& Ribeiro, F. M. (2016). Polinização do Meloeiro (Cucumis melo). Nutritime Revista Eletrônica, 5(1), 4815-4818. Retrieved from http://www.nutritime.com.br/arquivos_internos/artigos/Artigo_393.pdf 
Tschoeke, P. H., Oliveira, E. E., Dalcin, S. M., Silveira-Tschoeke, M. C. A. C., \& Santos, G. R. (2015). Diversity and flower-visiting rates of bee species as potential pollinators of melon (Cucumis melo L.) in the Brazilian Cerrado. Scientia Horticulturae, 81, 207-216. http://dx.doi.org/10.1016/j.scienta.2015.02.027

Witter, S., Nunes-Silva, P., Blochtein, B., Lisboa, B. B., \& Imperatriz-Fonseca, V. L. (2014). As abelhas e a agricultura (1st ed.). Porto Alegre: Ed. PUCRS.

Zar, J. H. (2010). Biostatistical Analysis (3rd ed.). New Jersey, Prentice Hall.

\section{Copyrights}

Copyright for this article is retained by the author(s), with first publication rights granted to the journal.

This is an open-access article distributed under the terms and conditions of the Creative Commons Attribution license (http://creativecommons.org/licenses/by/4.0/). 